\title{
A multidrug-resistant Klebsiella pneumoniae outbreak in a Peruvian hospital: Another threat from the COVID-19 pandemic
}

\author{
Kovy Arteaga-Livias MD, MSc(c) $)^{1,2,3}$ (1), Karim Pinzas-Acosta MD³, Lourdes Perez-Abad MD ${ }^{4}$, Vicky Panduro-Correa MD, MSc ${ }^{2}$, \\ Ali A. Rabaan PhD ${ }^{5}$, Samuel Pecho-Silva MD, MSc(c) ${ }^{3}$ and Bernardo Dámaso-Mata MD, MSc, DSc ${ }^{1,2}$ \\ ${ }^{1}$ Hospital II-EsSalud, Huánuco, Perú, ${ }^{2}$ Facultad de Medicina, Universidad Nacional Hermilio Valdizán, Huánuco, Perú, ${ }^{3}$ Universidad Científica del Sur, Lima, Perú, \\ ${ }^{4}$ Hospital Nacional Dos de Mayo, Lima, Perú and ${ }^{5}$ Molecular Diagnostic laboratory, Johns Hopkins Aramco Healthcare, Dhahran, Saudi Arabia
}

To the Editor-Since the report of the first cases of coronavirus disease 2019 (COVID-19), attempts have been undertaken to contain its expansion; however, to date there have been $>60$ million infections and $\sim 1.5$ million people have died. This pandemic has challenged all knowledge about public health in countries and institutions around the world, and in addition to the morbidity and mortality of the disease, other conditions have appeared that threaten public health. ${ }^{1}$

One of these situations that has not received adequate attention is the increase in bacterial resistance and the emergence of multidrug-resistant (MDR) strains, probably associated with multiple factors such as the collapse of health systems, self-medication of the population, indiscriminate use of antibiotics in hospitals, a false sense of security, and incorrect use of personal protective equipment (PPE). ${ }^{2}$

We reported an outbreak of Klebsiella pneumoniae New Delhi metallo- $\beta$-lactamase (NDM) in a Peruvian hospital where no cases of strains with this resistance had been identified previously. All patients were admitted for a diagnosis of COVID-19 and were placed in isolation and management areas for treatment. Table 1 shows the clinical characteristics of the patients included in the study.

Klebsiella pneumoniae MDR has become a threat to public health; by itself, it has virulence factors related to high mortality as well as low response to treatment. ${ }^{3}$ Klebsiella pneumoniae MDR was described for some time in Latin America and specifically in Peru in 2016, where an increased proportion of Enterobacteriaceae cases were carrying the NDM gene (67.5\%) compared to Klebsiella pneumoniae carbapenemase (KPC)-producing bacteria (31.3\%) and active-on-imipenem (IMP)-type NDM bacteria (1.2\%). ${ }^{4}$ Sacsaquispe et $\mathrm{al}^{5}$ determined that the main mechanism of resistance to carbapenems is the expression of blaNDM carbapenemase.

The COVID-19 pandemic has been superimposed on another pandemic, that of MDR bacteria. In our case, our hospital capacity was overwhelmed by patient overcrowding, so we managed patients with moderate and severe disease in patient reception areas and outpatient clinics in addition to opening a provisional intensive care unit (ICU) for critical patients. Under normal conditions, ICUs are the epicenters for the development of MDR bacteria. 6

Author for correspondence: Kovy Arteaga-Livias, E-mail: Farteaga@unheval.edu.pe Cite this article: Arteaga-Livias K, et al. (2022). A multidrug-resistant Klebsiella pneumoniae outbreak in a Peruvian hospital: Another threat from the COVID-19 pandemic. Infection Control \& Hospital Epidemiology, 43: 267-268, https://doi.org/ 10.1017 /ice.2020.1401
Another mechanism facilitating MDR spread is the irrational use of antibiotics, which were given due to the initial suspicion of superimposed infections. International reports indicate that up to $70 \%$ of hospitalized COVID-19 patients receive antibiotics, and these are often broad-spectrum agents, despite results that indicate a low proportion of bacterial infections. ${ }^{7}$ For this reason, treatment guidelines do not recommend the use of antibiotics in patients with mild or moderate disease unless the suspicion of bacterial confection is important. ${ }^{8}$

Cross contamination via the hands of the staff would be the main means of transmission; unfortunately, no further audit was possible due to the work overload in all areas of our hospital. Furthermore, the overload of the health systems and staff burnout may have decreased adherence to infection prevention and control, which may have facilitated the spread of MDR germs. ${ }^{9}$

The limited and inappropriate use of PPE is another factor to consider. ${ }^{2}$ Due to the great demand for this equipment, we experienced deficiencies in its availability and have had only 1 set of PPE to be used with all patients and throughout the shift, which could have facilitated the spread of germs from staff to the patients.

The hospital overflow and the isolation of health personnel with risk factors had to be mitigated by hiring young personnel who were poorly trained in the management of infections associated with health care. Suggestions for controlling the spread of bacterial resistance in the context of the COVID-19 pandemic include increasing the competencies of physicians in the proper treatment of SARS-CoV-2, correct recognition of symptoms of superimposed infections, eliminating the unnecessary use of antibiotics, and assessing the need for the use of devices that are known to increase the probability of infection. ${ }^{9}$

In addition, when treating a patient presenting with severe pneumonia due to COVID-19, in a state of immunological depression and in need of mechanical ventilation, it is necessary to consider the possibility of coinfection, as occurred with 2 of our patients. Thus, it is important to search for other bacteria with equal or greater virulence because coinfections may exist in hospitalized patients with COVID-19. ${ }^{10}$

In conclusion, while we find ourselves in a pandemic state due to a virus that is not yet fully understood, COVID-19 patients have an even higher risk of acquiring MDR bacterial infections, leading to a mortality rate even higher than that conferred by COVID-19 alone.

Acknowledgments. To the national reference laboratory for intra-hospital infections of the Instituto Nacional de Salud (INS).

(c) The Author(s), 2021. Published by Cambridge University Press on behalf of The Society for Healthcare Epidemiology of America. This is an Open Access article, distributed under the terms of the Creative Commons Attribution licence (http://creativecommons.org/licenses/by/4.0/), which permits unrestricted re-use, distribution, and reproduction in any medium, provided the original work is properly cited. 
Table 1. Clinical Characteristics of Patients With Positive Culture for Multidrug-Resistant Klebsiella pneumoniae

\begin{tabular}{|c|c|c|c|c|}
\hline Characteristic & Patient 1 & Patient 2 & Patient 3 & Patient 4 \\
\hline Age, y & 62 & 66 & 45 & 52 \\
\hline Sex & Male & Male & Male & Male \\
\hline Medical history & $\begin{array}{l}\text { High blood pressure, } \\
\text { hypothyroidism }\end{array}$ & None & Obesity & None \\
\hline Time since onset, $d$ & 7 & 14 & 8 & 12 \\
\hline Previous medication & $\begin{array}{l}\text { Hydroxychloroquine } \\
\text { Amoxicillin/ } \\
\text { clavulanic acid }\end{array}$ & $\begin{array}{l}\text { Ceftazidime } \\
\text { Ciprofloxacin }\end{array}$ & Ceftriaxone & $\begin{array}{l}\text { Ceftriaxone } \\
\text { Azithromycin }\end{array}$ \\
\hline $\mathrm{PaO}_{2} / \mathrm{FiO}_{2}$ on entry & 191 & 150 & 178 & 200 \\
\hline Diagnosis on entry & $\begin{array}{l}\text { Type } 1 \text { ARF } \\
\text { Moderate } \\
\text { COVID-19 } \\
\text { ARDS }\end{array}$ & $\begin{array}{l}\text { Type } 1 \text { ARF } \\
\text { Severe } \\
\text { COVID-19 ARDS }\end{array}$ & $\begin{array}{l}\text { Type } 1 \text { ARF } \\
\text { Moderate COVID-19 ARDS }\end{array}$ & $\begin{array}{l}\text { Type } 1 \text { ARF } \\
\text { Moderate } \\
\text { COVID-19 } \\
\text { ARDS }\end{array}$ \\
\hline Hospital entry date & Aug 21, 2020 & Aug 16, 2020 & Aug 14, 2020 & Aug 27, 2020 \\
\hline Days hospitalized prior to ICU admission & 4 & 6 & 19 & 1 \\
\hline Date of ICU entry & Aug 25, 2020 & Aug 22, 2020 & Sept 3, 2020 & Aug 28, 2020 \\
\hline Treatment received in ICU & $\begin{array}{l}\text { Ceftazidime } \\
\text { Ciprofloxacin } \\
\text { Colistin } \\
\text { Gentamicin }\end{array}$ & $\begin{array}{l}\text { Imipenem } \\
\text { Vancomycin } \\
\text { Gentamicin } \\
\text { Nitrofurantoin }\end{array}$ & $\begin{array}{l}\text { Imipenem } \\
\text { Vancomycin } \\
\text { Ertapenem } \\
\text { Clarithromycin }\end{array}$ & $\begin{array}{l}\text { Piperacillin/ } \\
\text { Tazobactam } \\
\text { Gentamicin } \\
\text { Colistin }\end{array}$ \\
\hline Date of endotracheal secretion culture & Sept 13, 2020 & Sept 2, 2020 & Sept 13, 2020 & Sept 7, 2020 \\
\hline Days in ICU & 29 & 27 & 18 & 11 \\
\hline Superimposed infection & Acinetobacter baumannii & None & Serratia marcescens & None \\
\hline Resistance genes & $\begin{array}{l}\text { NDM } \\
\text { CTX-M }\end{array}$ & $\begin{array}{l}\text { NDM } \\
\text { CTX-M }\end{array}$ & $\begin{array}{l}\text { NDM } \\
\text { CTX-M }\end{array}$ & $\ldots$ \\
\hline Date of death & Sept 24, 2020 & Sept 17, 2020 & Sept 21, 2020 & $\ldots$ \\
\hline Date of discharge & $\ldots$ & $\ldots$ & $\ldots$ & Oct 6,2020 \\
\hline
\end{tabular}

Financial support. No financial support was provided relevant to this article.

Conflicts of interest. All authors report no conflicts of interest relevant to this article.

\section{References}

1. Arteaga-Livias FK, Rodriguez-Morales AJ. La comunicación científica y el acceso abierto en la contención de enfermedades: el caso del coronavirus novel 2019 (2019-nCoV). Rev Peru Investig En Salud 2020;4:7-8.

2. Donà D, Di Chiara C, Sharland M. Multidrug-resistant infections in the COVID-19 era: a framework for considering the potential impact. J Hosp Infect 2020;106:198-199.

3. Li Q, Zhu J, Kang J, et al. Emergence of NDM-5-producing carbapenemresistant Klebsiella pneumoniae and SIM-producing hypervirulent Klebsiella pneumoniae isolated from aseptic body fluid in a large tertiary hospital, 2017-2018: genetic traits of blaNDM-like and blaSIM-like genes as determined by NGS. Infect Drug Resist 2020; 13:3075-3089.
4. Pons MJ, Marí-Almirall M, Ymaña B, et al. Spread of ST348 Klebsiella pneumoniae producing NDM-1 in a Peruvian hospital. Microorganisms 2020;8:1392.

5. Sacsaquispe-Contreras R, Bailón-Calderón H. Identificación de genes de resistencia a carbapenémicos en enterobacterias de hospitales de Perú, 2013-2017. Rev Peru Med Exp Salud Pública 2018;35:259.

6. Bengoechea JA, Bamford CG. SARS-CoV-2, bacterial coinfections, and AMR: the deadly trio in COVID-19? EMBO Mol Med 2020;12:e12560.

7. Monnet DL, Harbarth S. Will coronavirus disease (COVID-19) have an impact on antimicrobial resistance? Euro Surveill Bull 2020;2(45): pii $=2001886$.

8. Getahun H, Smith I, Trivedi K, et al. Tackling antimicrobial resistance in the COVID-19 pandemic. Bull WHO 2020;98:442-442A.

9. Bogossian EG, Taccone FS, Izzi A, et al. The acquisition of multidrugresistant bacteria in patients admitted to COVID-19 intensive care units: a monocentric retrospective case control study. Microorganisms 2020;8:1821.

10. Porretta AD, Baggiani A, Arzilli G, et al. Increased risk of acquisition of New Delhi metallo-beta-lactamase-producing carbapenem-resistant enterobacterales (NDM-CRE) among a cohort of COVID-19 patients in a teaching hospital in Tuscany, Italy. Pathogens 2020;9:635. 